\title{
Antennatus linearis, a New Indo-Pacific Species of Frogfish (Lophiiformes: Antennariidae) ${ }^{1}$
}

\author{
Fobn E. Randall ${ }^{2}$ and Ronald R. Holcom ${ }^{3}$
}

\begin{abstract}
Antennatus linearis is described as a new species of frogfish (family Antennariidae) from three specimens from the Hawaiian Islands, one from the Molucca Islands, one from Aldabra, and four from Mozambique and Natal, South Africa, the largest $60 \mathrm{~mm}$ standard length. It is distinct from the wideranging Indo-Pacific $A$. tuberosus in having a caudal peduncle, 9-10 instead of 11-12 (rarely 10) pectoral rays, usually all or all but one of the pectoral rays branched (usually all simple in $A$. tuberosus), longer and more widely spaced dermal spicules, and a longer second dorsal spine (10.5-13.4\% SL, compared with $6.5-9.8 \%$ for $A$. tuberosus). It differs from the eastern Pacific $A$. strigatus and the Japanese $A$. flagellatus in having the illicium 1.55-1.95 times longer than the second dorsal spine (about equal to the second spine in $A$. strigatus, and about 3.6 times longer in $A$. flagellatus). It differs from all three species in its striking pattern of curving dark lines on the head and body.
\end{abstract}

The frogfish genus Antennatus Schultz is distinct from the 11 other genera of the family Antennariidae in having the skin covered with very close-set bifurcate spinules, lacking naked areas between the lateral-line pores, the illicium (modified first dorsal spine) without spinules and without a distinct esca (bait), the third dorsal spine immobile, dorsal soft rays $11-13$, anal rays $6-8$, and pectoral rays 9-12 (Pietsch and Grobecker 1987). Two species were recognized in the genus by Pietsch and Grobecker, the wide-ranging Indo-Pacific $A$. tuberosus (Cuvier) and the eastern Pacific $A$. strigatus (Gill). Ohnishi et al. (1997) added a third species, A. flagellatus, from southern Japan, distinct in having the illicium about 3.6 times longer than the second dorsal spine, and having a caudal peduncle (in the other two species, the last membrane of the dorsal and anal fins attaches to or beyond the base of the caudal fin). All

\footnotetext{
${ }^{1}$ Manuscript accepted 16 June 2000.

2 Bishop Museum, 1525 Bernice Street, Honolulu, Hawai'i 96817-2704 (E-mail: jackr@hi.net).

${ }^{3}$ P.O. Box 240454, Honolulu, Hawai'i 96824.
}

Pacific Science (2001), vol. 55, no. 2:137-144

(C) 2001 by University of Hawai'i Press.

All rights reserved three species are small; the largest specimen is $78 \mathrm{~mm}$ SL.

Two specimens of Antennatus were collected in the Hawaiian Islands, one in 1991 and the other in 1995, that differ from $A$. tuberosus in having fine, close-set, curving, dark lines over all the head and body. Because nothing else seemed different from $A$. tuberosus, and this color form was illustrated as $A$. tuberosus by Pietsch in Smith and Heemstra (1986: fig.102.8, from northern Mozambique), the specimens were identified as $A$. tuberosus (though with a question mark).

R.R.H. collected a small individual of this frogfish about $6 \mathrm{~mm}$ in total length in early 1997 and reared it in his aquarium to $41.4 \mathrm{~mm}$ SL by January 2000, at which time it became a specimen in the Bishop Museum. It had the linear color pattern from the juvenile to the adult stage. A closer examination of this and the other two Hawaiian specimens revealed some differences from $A$. tuberosus in addition to color. All have 10 pectoral rays, two with 9 on the other side (usually 11 in $A$. tuberosus), the anal rays are all branched, or all but the last branched (usually all unbranched in $A$. tuberosus), the second dorsal spine is longer (10.4-12.5\% SL, compared with $6.5-9.8 \%$ for $A$. tuberosus), the dermal spicules on the head and body are larger and not as densely spaced, and there is a short caudal peduncle. 
A request was made for a loan of material of Antennatus tuberosus from the J. L. B. Smith Institute of Ichthyology in Grahamstown, South Africa. Thirteen specimens were sent, including four from Mozambique and Natal with the same unique linear pattern. Four other specimens of the loan from southeastern Africa and one from the Comoro Islands appear to be the same species but lack the dark lines (possibly the result of fading). These are not designated as paratypes.

One specimen of the new species from Aldabra in the southern Seychelles was obtained from the Natural History Museum in London; one from Maui, Hawaiian Islands, from the California Academy of Sciences; and one from the Molucca Islands, Indonesia, from the U.S. National Museum of Natural History.

We have no hesitation in describing this fourth frogfish of the genus Antennatus as a new species. It is expected that further collecting in the Indo-Pacific region will result in additional localities.

\section{MATERIALS AND METHODS}

Type specimens of the new species have been deposited in the Natural History Museum, London (вмNн); Bernice P. Bishop Museum, Honolulu (врвм); California Academy of Sciences, San Francisco (cas); J. L. B. Smith Institute of Ichthyology, Grahamstown, South Africa (RUSI); and the U.S. National Museum of Natural History, Washington, D.C. (USNM).

Lengths recorded for specimens are standard length (SL), the straight-line distance from the most anterior point of the snout to the base of the caudal fin (posterior end of hypural plate). Two measurements were taken of body depth, the maximum depth (which can vary greatly from specimen to specimen) and the depth at the origin of the anal fin; body width is measured from the axil of one pectoral fin to that of the other; head width is the greatest width; snout length is from the median anterior point of the snout to the bony edge of the orbit; orbit diameter is the maximum bony diameter, and interorbital width the minimum bony width (for Anten- natus, this is the anterior interorbital); caudalpeduncle length is the horizontal distance between verticals at the rear base of the anal fin and the base of the caudal fin; predorsal length is from the origin of the soft dorsal fin to the front of the snout; illicium length includes the small spinule-covered basal part; the second dorsal spine is measured from the middle of its base, whereas the third dorsal spine is measured along its anterior edge; fin lengths are the lengths of the longest rays. All specimens were $\mathrm{X}$-rayed to facilitate the taking of counts and some of the above measurements.

Meristic and morphometric data given in parentheses in the description of the new species refer to paratypes. Table 1 provides the pectoral-ray counts for the new species and Antennatus tuberosus; counts were made of the fins of both sides. Table 2 contains the measurements of type specimens of the new species as percentages of the standard length. Proportional measurements in the text are rounded to the nearest 0.05 .

Antennarius linearis Randall \& Holcom, n. sp. Figures 1-4; Tables 1, 2

Antennatus tuberosus (non Cuvier) Pietsch in Smith and Heemstra, 1986:369, fig. 102.8, bottom (N. Mozambique).

Antennatus tuberosus (non Cuvier) Pietsch \& Grobecker, 1987:192 (Mozambique).

HOLOTYPE: вРвм 38704, $41.4 \mathrm{~mm}$, Hawaiian Islands, O'ahu, off Kahe Point, 14 m, collected as a juvenile from under coral rubble in early 1997, R. R. Holcom, maintained in aquarium until 17 January 2000.

PARATYPES: RUSI $4605,44.8 \mathrm{~mm}$, Mozambique, Pinda Islands, $14^{\circ} 13^{\prime} \mathrm{S}, 40^{\circ} 46^{\prime} \mathrm{E}$, J. L. B. Smith and M. M. Smith, 20 September 1956; RUSI 4607, $54.5 \mathrm{~mm}$, South Africa, Natal, Durban, $29^{\circ} 51^{\prime} \mathrm{S}, 31^{\circ} 00^{\prime} \mathrm{E}, \mathrm{J}$. L. B. Smith and M. M. Smith, 7 May 1963; Rusi 4609, $58.8 \mathrm{~mm}$, Mozambique, Maputo, $25^{\circ} 58^{\prime} \mathrm{S}, 32^{\circ} 35^{\prime} \mathrm{E}, \mathrm{J}$. L. B. Smith and M. M. Smith, 6 May 1967; UsNm 209596, $20.5 \mathrm{~mm}$, Indonesia, Molucca Islands, Haruku Island, point $\mathrm{E}$ of Tandjung Naira, surge channel, $4.5 \mathrm{~m}$, rotenone, V. G. Springer and M. F. 


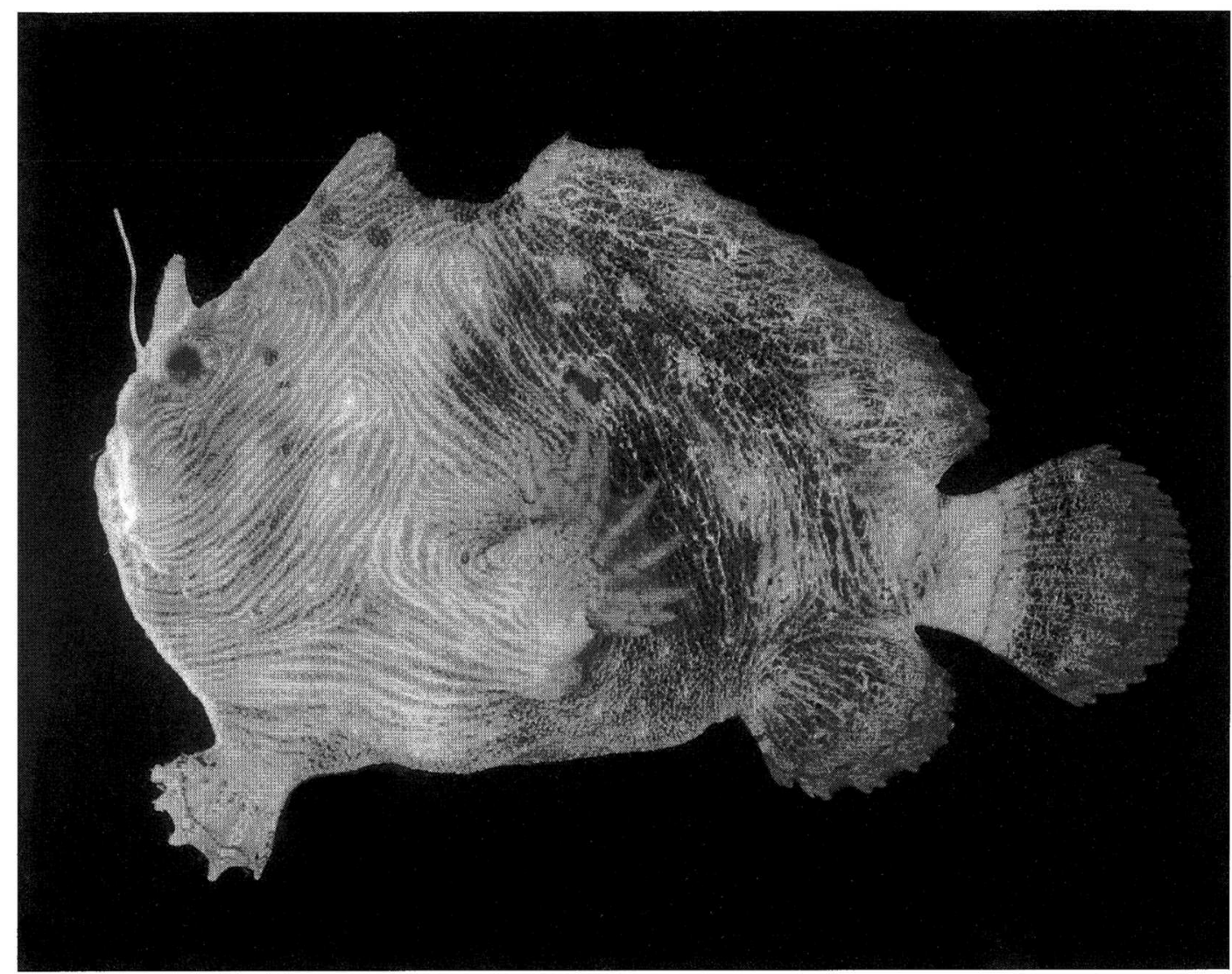

Figure 1. Holotype of Antennatus linearis, врвм 38704, 41.4 mm SL, O‘ahu, Hawaiian Islands (J. E. Randall).

Gomon, 15 January 1973; вРвм 37232, $42.2 \mathrm{~mm}$, Hawaiian Islands, O'ahu, Mākua, sparse rubble and sand, $21.5 \mathrm{~m}$, hand net, J. L. Earle, 14 March 1991; USNM 361066, 52 mm, Hawaiian Islands, O'ahu, off Wai'anae, from pet store, B. Nagareda, died in aquarium 20 December 1996; RUSI 56816, $38.2 \mathrm{~mm}$, KwaZulu-Natal, Sodwana Bay, 5-Mile Reef, $27^{\circ} 29^{\prime} 27^{\prime \prime} \mathrm{S}, 32^{\circ} 41^{\prime} 36^{\prime \prime}$ E, P. C. Heemstra, E. Heemstra, D. S. Polack, and J. Dench, 13 August 1997.

OTHER MATERIAL EXAMINED: BMNH 1980.11.20.11, $45.5 \mathrm{~mm}$, Seychelles, Aldabra; CAS 42882, $34.5 \mathrm{~mm}$, Hawaiian Islands, Maui; RUSI 4606, $19 \mathrm{~mm}$, Mozambique, Nangata; RUSI 4608, $19 \mathrm{~mm}$, Mozambique, Pinda Island; Rusi 4610, $70 \mathrm{~mm}$, Hibberdene, Natal; RUSI 30945, 37 mm, Comoro Islands, Grande
Comore; Rusi 46303, 23 mm, Natal, Aliwal Shoal.

DiAgnosis: Dorsal soft rays 12; anal soft rays 7 , four to 7 branched; pectoral rays $9-10$ (usually 10); short caudal peduncle present (except one paratype); illicium without a distinct esca, its length 1.4-2.0 times length of second dorsal spine; second dorsal spine tapering, 10.2-13.4\% SL; light brown with two sets of numerous, parallel, curving, dark brown lines, one on body extending downward and posteriorly, then curving forward on abdomen, the other on head curving upward and posteriorly from chin; large, obscure, blackish blotches sometimes present on body.

DESCRIPTION: Dorsal rays $\mathrm{I}+\mathrm{I}+1+12$, the penultimate soft ray branched (varying 


\section{TABLE}

Pectoral-Ray Counts of Antennatus linearis and A. tuberosus

\begin{tabular}{lllll}
\hline \hline Species & 9 & 10 & 11 & 12 \\
\hline A. linearis & 2 & 28 & & \\
A. tuberosus $^{a}$ & & 11 & 61 & 6 \\
\hline
\end{tabular}

${ }^{a}$ Specimens from Bishop Museum, California Academy of Sciences, and J. L. B. Smith Institute of Ichthyology.

in paratypes from none branched to fifth to last branched); anal rays 7, all but last branched (all or all but one branched in five paratypes, one with third to sixth rays branched); caudal rays 9, the median 7 branched; pectoral rays 9-10 (9-10, usually 10 [see Table 1]); pelvic rays I,5; vertebrae $10+8$.

Body deep, the maximum depth 1.55 $(1.35-1.7)$ in SL; body depth at origin of anal fin 2.8 (2.75-3.3) in SL; body compressed, the width 2.8 (2.45-3.1) in maximum depth; snout to gill opening $1.6(1.55-1.8)$ in SL; snout length 10.75 (10.8-11.8) in SL; orbit diameter 11.9 (11.6-13.9) in SL; caudalpeduncle depth 6.6 (6.4-7.3) in SL; caudal peduncle very short, its length 32.3 (29.437.0 ) in SL (one paratype with no caudal peduncle, but it seems aberrant in this character).

Mouth large, the upper-jaw length 5.05 (4.55-5.1) in SL, and strongly oblique, the gape forming an angle of about $70^{\circ}$ to horizontal axis of head and body; lower jaw projecting; front of upper jaw with two rows of slender, incurved and inwardly depressible, conical teeth, the teeth of inner row about twice as long as those of outer row; outer row of small teeth continuing as a single row on side of jaw; lower jaw with three rows of slender, inward-projecting and depressible conical teeth, the outer row small, the longest teeth of inner row about three times length of those in outer row; each side of vomer with a broad patch of slender conical teeth in three irregular rows, the inner teeth longer; palatines with an oval patch of small, slender conical teeth in three rows, the medial teeth largest. Tongue short, very thick, and broadly rounded, with scattered small papillae on upper surface. Lips thin, the upper lip narrow, both with numerous small papillae, the largest along edge of lower lip; a small median fleshy protuberance projecting downward from upper lip. Anterior nostril (damaged in holotype) a small membranous tube, about half pupil diameter in length, anterior to middle of eye just above upper lip; posterior nostril with a slight rim, dorsoposterior to anterior nostril, the internarial distance about equal to length of tube of anterior nostril.

Head, body, and fins except outer part of membranes densely covered with small bifurcate dermal spicules (bifurcate tips enclosed in tissue in some specimens, including the holotype, thus obscuring the tips). Lateralis system associated with irregular wartlike clusters of very dense dermal spicules, with no naked areas between the clusters.

Illicium behind a short, broad median groove at front of snout, and directly before base of second dorsal spine; illicium without spicules (except on short, broad basal part), tapering very slightly, and without an obvious esca (esca in the form of a slightly expanded tip or with a short, tapering filament present on some paratypes); illicium length 5.0 (4.85$5.6)$ in SL, $1.9(1.55-1.95)$ times length of second dorsal spine; second dorsal spine tapering only slightly, folding into a shallow posterior groove, and with a slight medial membrane in axil, the spine length 9.6 (8.09.55) in SL; third dorsal spine tightly bound by skin, forming an equilateral triangle with the skin extending from tip to dorsum when spine elevated to its maximum, the spine length 4.7 (4.3-4.7) in SL; a definite gap between the origin of the dorsal fin and posterior skin connecting the third dorsal spine to the back; origin of soft dorsal fin above upper base of pectoral fins, the predorsal length 2.1 (2.15-2.3) in SL; eighth or ninth dorsal soft ray longest, 4.15 (4.1-4.65) in SL; origin of anal fin below base of ninth dorsal soft ray, the preanal distance $1.2(1.1-1.2)$ in SL; caudal fin broadly rounded, 3.6 (3.55-4.1) in SL; third or fourth pectoral ray longest, 5.7 (5.25-5.7) in SL; pelvic spine small and slender, detectable only by $\mathrm{X}$ ray or dissection; 
TABLE 2

Proportional Measurements of Type Specimens of Antennatus linearus Expressed as Percentages of the Standard Length

\begin{tabular}{|c|c|c|c|c|c|c|c|}
\hline \multirow[b]{2}{*}{ Measurement } & \multirow{2}{*}{ 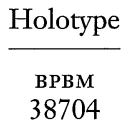 } & \multicolumn{6}{|c|}{ Paratypes } \\
\hline & & $\begin{array}{c}\text { RUSI } \\
56816\end{array}$ & $\begin{array}{r}\text { BPBM } \\
37232\end{array}$ & $\begin{array}{l}\text { RUSI } \\
4605\end{array}$ & $\begin{array}{c}\text { USNM } \\
361066\end{array}$ & $\begin{array}{l}\text { RUSI } \\
4607\end{array}$ & $\begin{array}{l}\text { RUSI } \\
4609\end{array}$ \\
\hline Standard length $(\mathrm{mm})$ & 41.4 & 38.2 & 42.2 & 44.8 & 52.0 & 54.5 & 58.8 \\
\hline Maximum body depth & 65.0 & 70.2 & 73.1 & 65.8 & 70.3 & 59.0 & 60.6 \\
\hline Body depth (anal origin) & 35.5 & 36.3 & 33.6 & 32.4 & 34.5 & 30.4 & 30.7 \\
\hline Body width & 23.4 & 25.5 & 23.6 & 24.1 & 22.8 & 24.2 & 23.4 \\
\hline Snout to gill opening & 63.0 & 63.7 & 60.2 & 62.3 & 62.8 & 55.5 & 61.5 \\
\hline Head width & 31.3 & 34.3 & 32.7 & 31.2 & 30.4 & 33.2 & 34.0 \\
\hline Snout length & 9.3 & 9.2 & 9.1 & 8.8 & 8.8 & 8.9 & 8.5 \\
\hline Orbit diameter & 8.4 & 8.6 & 8.3 & 7.6 & 7.9 & 7.5 & 7.2 \\
\hline Interorbital width & 11.8 & 11.0 & 11.1 & 11.4 & 11.4 & 11.2 & 11.9 \\
\hline Caudal-peduncle depth & 15.2 & 15.7 & 14.3 & 14.8 & 15.1 & 14.3 & 13.7 \\
\hline Caudal-peduncle length & 3.1 & 3.4 & 2.5 & 2.4 & 3.0 & 2.7 & 0 \\
\hline Upper-jaw length & 19.8 & 20.9 & 22.0 & 19.7 & 20.7 & 21.8 & 21.0 \\
\hline Predorsal length & 47.1 & 44.5 & 43.1 & 44.7 & 46.2 & 43.8 & 46.0 \\
\hline Preanal length & 82.2 & 87.2 & 89.0 & 87.0 & 85.5 & 83.1 & 85.9 \\
\hline Prepelvic length & 41.3 & 48.0 & 47.0 & 44.6 & 40.4 & 42.9 & 44.2 \\
\hline Illicium length & 20.0 & 19.6 & 19.0 & 17.9 & 20.6 & 19.8 & broken \\
\hline Second dorsal spine & 10.4 & 12.5 & 11.8 & 11.1 & 10.7 & 10.5 & 11.4 \\
\hline Third dorsal spine & 21.3 & 21.2 & 21.5 & 21.3 & 21.2 & 23.2 & aberrant \\
\hline Longest dorsal ray & 24.2 & 22.3 & 23.2 & 22.1 & 24.4 & 22.1 & 21.6 \\
\hline Longest anal ray & 19.5 & 18.3 & 19.7 & 19.8 & 19.2 & 20.2 & 20.6 \\
\hline Caudal-fin length & 28.0 & 28.2 & 26.3 & 25.2 & 27.0 & 26.8 & 24.5 \\
\hline Pectoral-fin length & 17.3 & 18.5 & 18.5 & 17.4 & 18.3 & 19.1 & 17.3 \\
\hline Pelvic-fin length & 15.2 & 14.8 & 15.2 & 14.9 & 15.1 & 14.9 & 15.0 \\
\hline
\end{tabular}

second to fourth pelvic rays subequal, the third usually longest, 6.6 (6.6-6.75) in SL.

Color of holotype in alcohol: head and body pale with three sets of numerous, parallel, curving, blackish lines, one on body extending downward and posteriorly, then curving forward on abdomen, one on head curving upward and posteriorly from chin, and the third in a small triangular area behind the head with the lines converging onto the pectoral-fin base; large, obscure, dark blotches on body, the result of the dark lines within the blotches being broader and more darkly pigmented; wartlike dense clusters of spinules on body tend to be pale, whereas some small ones on head are dark; soft dorsal fin blackish with whitish blotches except for translucent outer naked membranes; anal fin similar to soft dorsal fin, but with an irregular double submarginal dark line; caudal fin pale with a transverse blackish line across basal fifth of fin, a broad blackish bar in middle of fin, and a submarginal narrow zone of dark lines forming a reticulum; pectoral fins pale with a reticulum of fine blackish lines; pelvic fins colored like body basally, the outer part pale with a distal zone of dark lines forming a reticulum.

In life the lines on the head and anterior part of the body of the holotype were orangish brown, whereas they were mostly blackish on the body; a complex lacelike pattern of fine white lines was superimposed on the linear pattern of the dorsoposterior part of the body and the soft dorsal and anal fins (see Figure 2).

None of the lines on the body of paratypes USNM 361066 (Figure 3) and врвм 37232 was blackish as on the holotype, although there was variation in intensity of the brown lines such that some large darker blotches were evident. Also they had scattered orange-red spots of various sizes on the head and body, 


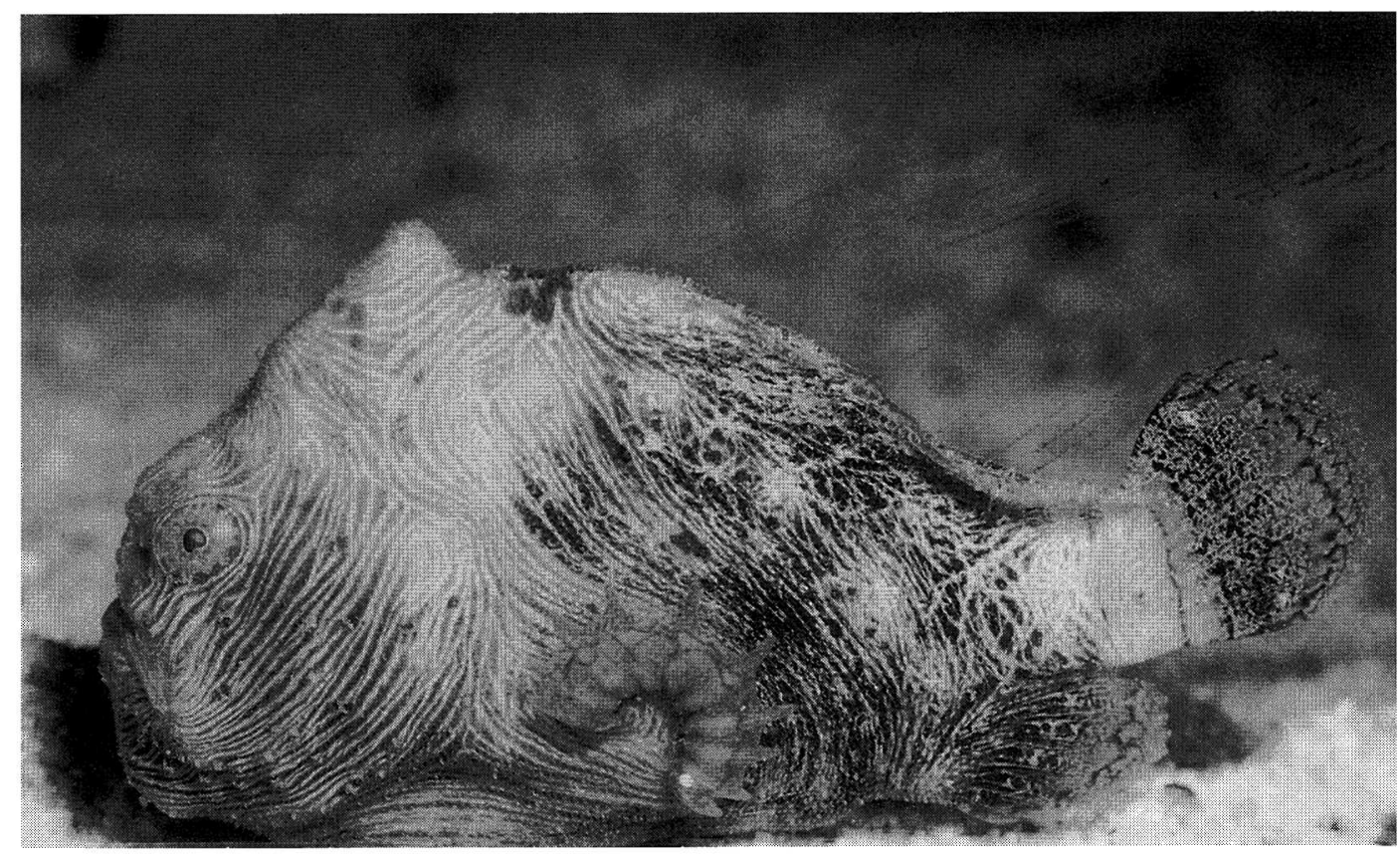

Figure 2. Aquarium photograph of holotype of Antennatus linearis (R. R. Holcom).

most associated with the wartlike clusters of dense dermal spicules.

etymology: This species is named $A n$ tennatus linearis from the Latin, in reference to its unique pattern of lines on the head and body.

REMARKs: Antennatus linearis is currently known only from the Hawaiian Islands, Molucca Islands, Aldabra and the Comoro Islands in the western Indian Ocean, and the coast of East Africa from northern Mozambique to Durban.

In Hawail $\mathrm{i}$, at least, this species is more cryptic than Antennatus tuberosus. John L. Earle, the collector of one of the type specimens, informed us that he has seen it several times when turning over rocks looking for mollusks.

R.R.H. reared the holotype from a juvenile. He fed it brine shrimp initially and later guppies (Poecilia reticulata) and freshwater shrimp obtained from a local pet store. He also fed it some small fishes that he caught alive while diving, including the gobies Gnatholepis anjerensis and G. cauerensis, the blenny
Blenniella gibbifrons, and an unidentified small sole. Other aquarium residents, the cleaner shrimp Lysmata amboinensis and a reproducing pair of cardinalfishes (Apogonichthys perdix), were unintended prey. The holotype used its illicium as a lure even though it lacked an obvious esca.

John P. Hoover photographed a juvenile of about $10 \mathrm{~mm}$ total length underwater in July 1996 off Kahe Point, O'ahu (hence the same locality where the holotype was collected). His photograph is reproduced here as Figure 4.

Type specimens have been collected at depths of $4.5-33 \mathrm{~m}$.

This species has been misidentified as $A n$ tennatus tuberosus perhaps because it shares some important characters that serve to separate $A$. tuberosus from $A$. strigatus of the eastern Pacific, such as the illicium being 1.5-2 times longer than the second dorsal spine, its being finely tapering and without a distinct esca, and the second dorsal spine being cylindrical and not tapering. It differs from $A$. tuberosus in having modally 10 instead of 11 


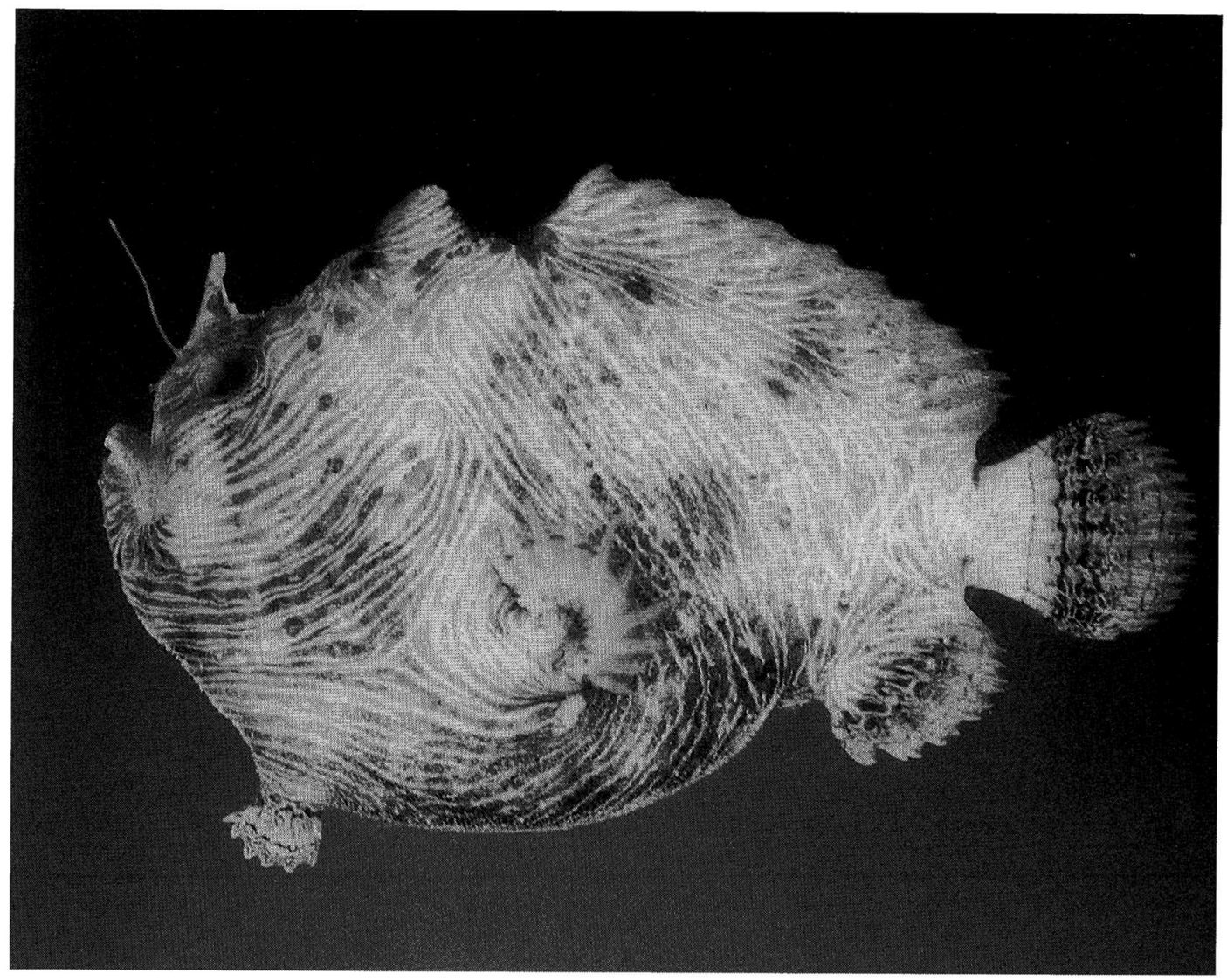

Figure 3. Paratype of Antennatus linearis, usnm 361066, 52.0 mm SL, O'ahu, Hawaiian Islands (J. E. Randall).

pectoral rays, all or all but one of the anal rays branched (usually all simple in $A$. tuberosus), caudal peduncle present, longer and more widely spaced dermal spicules, a longer second dorsal spine $(10.5-13.4 \%$ SL, compared with $6.5-9.8 \%$ for $A$. tuberosus), and its distinct linear color pattern.

Antennatus flagellatus of southern Japan is readily separated by the very long illicium (about 3.6 times the length of the second dorsal spine), by lacking a gap between the skin of the third dorsal spine and the origin of the soft dorsal fin, and by color (illustrations of $A$. flagellatus by Ohnishi et al. [1997: fig. 1]).

Antennatus strigatus of the eastern Pacific is distinct from $A$. linearis in having a short illicium (about equal in length to the second dorsal spine), a conical and tapering second dorsal spine, and by color.

\section{ACKNOWLEDGMENTS}

We thank the collectors of type specimens as listed above. We thank also the following for loan of specimens of Antennatus: Andrew Bentley of the J. L. B. Smith Institute of Ichthyology, David Catania and Jon Fong of the California Academy of Sciences, Anthony C. Gill of the Natural History Museum in London, and Jeffrey T. Williams of the U.S. National Museum of Natural History. Thanks are also due John P. Hoover for the 


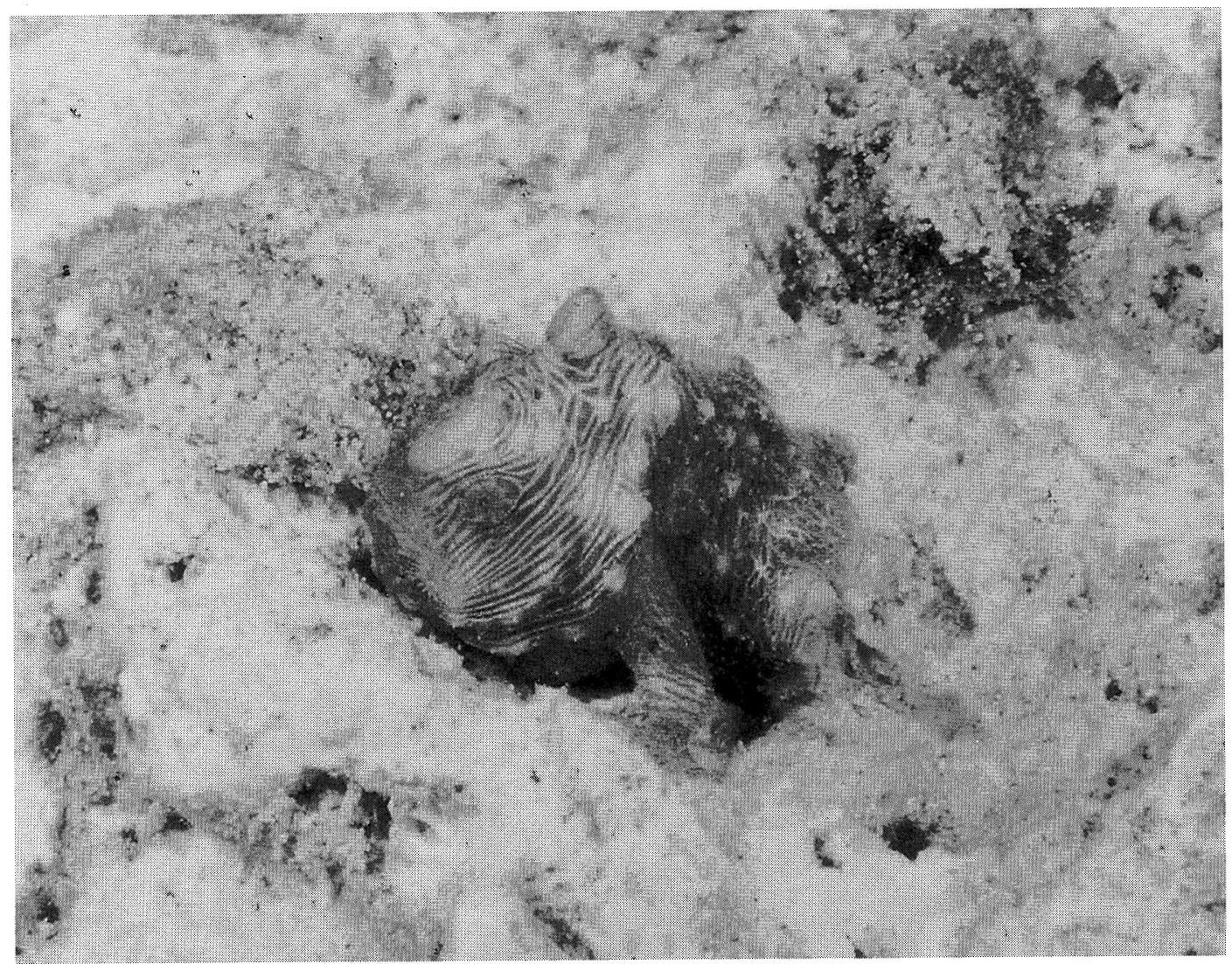

Figure 4. Underwater photograph of juvenile of Antennatus linearis, about $10 \mathrm{~mm}$ total length, O'ahu, Hawaiian Islands (J. P. Hoover).

underwater photograph of a juvenile of $A$. linearis and David W. Greenfield for X rays. Greenfield and Theodore W. Pietsch reviewed the manuscript.

\section{Literature Cited}

Ohnishi, N., A. Iwata, and W. Hiramatsu. 1997. Antennatus flagellatus (Teleostei:
Antennariidae), a new species of frogfish from southern Japan. Ichthyol. Res. 44 (2): 213-217.

Pietsch, T. W., and D. B. Grobecker. 1987. Frogfishes of the world. Stanford University Press, Stanford, California.

Smith, M. M., and P. C. Heemstra. 1986. Smiths' sea fishes. Macmillan South Africa, Johannesburg. 